\begin{tabular}{|c|c|c|}
\hline 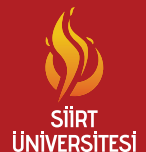 & $\begin{array}{c}\text { Türkiye Tarımsal Araştırmalar Dergisi } \\
\text { dergipark.org.tr/tutad }\end{array}$ & $\begin{array}{l}\text { Turk J Agric Res } \\
\text { 2021, 8(3): 273-281 } \\
\text { @ TÜTAD } \\
\text { ISSN: 2148-2306 } \\
\text { e-ISSN: 2528-858X }\end{array}$ \\
\hline Bdimin Psugunda & Araştırma Makalesi / Research Article & doi: $10.19159 /$ tutad.958720 \\
\hline
\end{tabular}

\title{
Farklı Biçim Devresinin ve Arpa Kırması Uygulamalarının Tek Yıllık Yem Bitkileri Karışımının Silaj Özelliklerine Etkileri
}

\author{
Esra GÜRSOY ${ }^{*}$, Emre KARA ${ }^{2}$, Mustafa SÜRMEN ${ }^{2}$ \\ ${ }^{I}$ Ağrı İbrahim Çeçen Üniversitesi, Eleşkirt Celal Oruç Hayvansal Üretim Yüksekokulu, Hayvan Yetiştirme ve Besleme Anabilim Dalı, Ağrl, \\ TÜRKIYE \\ ${ }^{2}$ Aydın Adnan Menderes Üniversitesi, Ziraat Fakültesi, Tarla Bitkileri Bölümü, Aydın, TÜRKIYE
}

\begin{tabular}{|c|c|}
\hline Geliş Tarihi/Received: 28.06 .2021 & Kabul Tarihi/Accepted: 10.12.2021 \\
\hline \multicolumn{2}{|l|}{ ORCID ID (Yazar surasina göre / by author order) } \\
\hline orcid.org/0000-0002-4697-7365 (1D) orcid.org/0000-0002-5s & cid.org/0000-0001-9748-618X \\
\hline
\end{tabular}

Öz: Bu çalışma; farklı fenolojik dönemlerde biçilen tek yıllık baklagil-buğdaygil çoklu karışımına uygulanan arpa kırması oranlarının, silaj kalitesi ve yem değerine etkilerini belirlemek amacıyla yürütülmüștür. Araștırmada, \% 35 Macar fiği $+\% 35$ yem bezelyesi $+\% 10$ yulaf $+\% 10$ tritikale $+\% 10$ buğday karışımı silaj materyali olarak kullanılmıştır. Ot hasadı üç farklı devrede (yem bezelyesinin çiçeklenme öncesi, \% 50 çiçeklenme, tam çiçeklenme dönemi) yapılmıştır. Üretilen kaba yemin silaj kalitesi ve yem değerine etkilerini belirlemek için dört farklı dozda ( $0, \% 5, \% 10$ ve \% 15) arpa kırması uygulanarak silajlar hazırlanmıştır. Silaj örnekleri vakumlu torbalarda $25 \pm 2^{\circ} \mathrm{C}^{\prime} \mathrm{de} 60$ gün süre ile fermantasyona bırakılmıştır. Fermantasyon sonunda açılan silajlardan alınan örneklerde; $\mathrm{pH}$, kuru madde, ham protein, ham kül, asit deterjanda çözünmeyen lif, nötral deterjanda çözünmeyen lif, asit deterjan lignin, kalsiyum, magnezyum ve fosfor analizleri yapılmıştır. Silajların Fleig puanı ve nispi yem değerleri de hesaplanarak kaba yemin kalitesi ortaya konmuştur. Araştırma sonucuna göre, biçim devresinin gecikmesi; silaj besin maddesi içeriklerini, hücre duvarı unsurlarını ve silaj fermantasyonunu etkilemiştir. Fleig puanı artan arpa oranına göre artarken, silajların nispi yem değeri "en iyi” kalitede yer almıştır. Arpa kırmasının \% 15 düzeyinde eklenmesi, silajların fermantasyonu ve silaj kalitesine olumlu yönde etki etmiştir. En yükssek nispi yem değeri, tam çiçeklenme döneminde biçilen ve \% 15 arpa kırması ilave edilen örneklerden elde edilmiștir. Sonuç olarak, çiçeklenme döneminde biçilen yem bitkileri karışımına \% 15 arpa kırması eklenerek yapılacak silajlar ile hayvanların kış döneminde kaliteli yeşil yem ihtiyacı karşılanabilecektir.

Anahtar Kelimeler: Fleig puanı, biçim devresi, arpa kırması, mineral madde, nispi yem değeri

\section{The Effects of Different Cutting Stage and Crushed Barley Applications on Silage Properties of Annual Forage Crops Mixture}

\footnotetext{
Abstract: This study was carried out to determine the effects of barley crushing rates applied to annual legume-grain multi mix harvested in different phenological periods on silage quality and feed value. In the research, $35 \%$ Hungarian vetch $+35 \%$ fodder pea $+10 \%$ oat $+10 \%$ triticale $+10 \%$ wheat mixture was used as silage material. Hay harvesting was carried out in three different stages (before flowering, 50\% flowering, the full flowering period of fodder pea). To determine the effects of the produced roughage on silage quality and feed value, silages were prepared by applying barley crushed at four different doses $(0,5 \%, 10 \%$, and $15 \%)$. Silage samples were left to ferment in vacuum bags at $25 \pm 2{ }^{\circ} \mathrm{C}$ for 60 days. In the samples taken from the silages opened at the end of fermentation; $\mathrm{pH}$, dry matter, crude protein, crude ash, acid detergent fiber, neutral detergent fiber, acid detergent lignin, calcium, magnesium, and phosphorus analyzes were made. The quality of the roughage was determined by calculating the Fleig score (FS) and relative feed values of the silages. According to the research results, the delay of the cutting stage affected the nutrient content, cell wall components, and fermentation of the silage. While the FS increased with increasing barley ratio, the relative feed value (RFV) was in the best quality. The addition of crushed barley at the level of $15 \%$ had a positive effect on the fermentation and silage quality of the silages. The highest RFV value was obtained from the samples harvested in full flowering and $15 \%$ crushed barley added. As a result, the silage to be made by adding $15 \%$
} 
crushed barley to the mixture of forage crops mowed during the flowering period will be able to meet the quality green fodder needs of the animals in the winter season.

Keywords: Fleig score, cutting stage, crushed barley, mineral matter, relative feed value

\section{Giriş}

Kaba yemler ruminant beslemede özellikle hayvanların fizyolojik aktiviteleri için oldukça önemlidir. İnsan beslenmesi ve ülke ekonomisi için büyük öneme sahip olan kaliteli hayvansal ürünleri elde etmek için çiftlik hayvanlarının kaliteli kaba yemlerle beslenmesi gerekmektedir. İstenilen özellik ve kalitede yem üretiminde; yem bitkisi tür ve çeşidinin etkisinin yanı sıra, biçim devresinin de yem kalitesine etkisinin olduğu bilinmektedir (Özyazıcı ve Açıkbaş, 2019). Erken dönemde biçilen yem bitkilerinin kalitesi yükselmekte, buna karşıllk verim azalmakta; biçim döneminin gecikmesi ile verim artışına rağmen, lignifikasyonun etkisi ile yem kalitesi ve lezzetinde azalmalar olmaktadır (Gürsoy ve Macit, 2020).

Türkiye'de, bölgelere ve ekolojilere göre farkl111k göstermekle beraber yılın her mevsiminde ot üretimi yapılamamaktadır. Bu nedenle üretilen kaliteli kaba yemlerin muhafazasinda yemler silolanarak uzun süre muhafaza edilmekte; böylece, hayvanların yeşil ve sulu yem ihtiyacı yem kaynaklarının az olduğu kış mevsiminde de karşılanmaktadır (Gülümser ve ark., 2019). Bu amaçla silolama, yem bitkisi cins ve türlerine göre birtakım farklılıklar göstermektedir. Protein bakımından zengin olan baklagillerle yapılan silolanma işleminde güçlüklerle karşı karşıya kalınmaktadır. Ancak buğdaygiller ise karbonhidrat bakımından zengin, buna karşılık protein içerikleri düşük olduğundan daha kolay silolanabilen türlerdir (Demirel ve ark., 2010). Baklagil ve buğdaygil yem bitkilerinin pozitif yönde etkilerini bir araya getirebilmek için son yıllarda saf ekim yerine karışım halinde yem bitkileri üretimi yaygınlaşmaya başlanmıştır.

Yem bitkileri kurutulduğunda özellikle baklagillerde büyük kayıplar olmaktadır (Önal ve Acar, 2018). Yapılan çalışmalarda; kurutulan ve depolanan kaba yemlere kiyasla silolanan baklagillerde kuru madde (KM) kaybının \% 30'dan $\%$ 5'e kadar, sindirilebilir protein kaybının $\% 35$ 'ten \% 5'e kadar ve nişasta kaybının ise \% 50'den \% 10'a kadar düştüğü bildirilmiştir (Bakır, 1987; Akdağ ve Garipoğlu, 2018). Ayrıca buğdaygil ve baklagil yem bitkileri karışımı ile hazırlanan silajların kurutmaya göre besin madde kayıplarının azalmasının yanında, besin madde içeriğinin arttığı da tespit edilmiştir (Sturludóttir, 2011; Öten ve ark., 2016). Bu nedenle silaj, yeşil yemlerin en az kayıpla muhafaza edilmesi için en iyi yöntem olarak karşımıza çıkmaktadır (Sarıçiçek ve Kılıç, 2009).

Fermantasyonu etkileyen faktörler; yeşil yemin solma derecesi, kesim uzunluğu, silolama teknolojisi ve kullanılan katkı madde miktarıdır (Haigh, 1988). Silaj kalitesi çok değişken olmakla beraber, silaj kalitesinin artması için fermantasyon sürecini kontrol eden bazı katk1 maddeleri kullanılmaktadır. Kullanılan katkı maddelerinin, kayıpları azalttığ1 ve silaj stabilitesini arttırdığ 1 bildirilmiştir (Yitbarek ve Tamir, 2014). Silaj katkı maddeleri; fermantasyon uyarıcıları (bakteri kültürü ve karbonhidrat kaynakları), fermantasyon inhibitörleri (asitler, formaldehit vb.), aerobik bozulma inhibitörleri (laktik asit bakterileri, propiyonik asit vb.), besinler (üre, amonyak vb.) ve emiciler (arpa, saman vb.) (McDonald ve ark., 1991) olmak üzere 5 ana gurupta toplanabilmektedir. Bazı baklagil yem bitkileri ve erken dönemde biçilen buğdaygillerin silolanmasında; melas, arpa kırması gibi materyaller karbonhidrat kaynağı olarak silajlarda kullanılmaktadır (Türemiş ve ark., 1997; Çiftçi ve ark., 2006; Dumlu ve Tan, 2009; Acar ve Bostan, 2016; Gülümser ve ark., 2019).

$\mathrm{Bu}$ araştırma, yem bitkileri karışımına farklı biçim dönemleri ve farklı oranlarda arpa kırması ilave edilmesi ile elde edilen silajların yem değerlerinin belirlenmesi amacıyla yürütülmüştür.

\section{Materyal ve Yöntem}

Çalışmanın tarla denemesi, Erzincan ili Altınbaşak Beldesi'nde bulunan bir çiftçi tarlasında, 20192020 sezonunda yürütülmüştür. Araştırmada, tek y1llık yem bitkilerinden Macar fiğgi (Vicia pannocia) ve yem bezelyesi (Pisum arvense L.)'nin yulaf (Avena sativa L.), tritikale (x Triticosecale Wittmack) ve buğday (Triticum aestivum) tahılları ile karışımı (\% 35 Macar fiğ i $+\% 35$ yem bezelyesi $+\% 10$ yulaf $+\% 10$ tritikale $+\% 10$ buğday) silaj materyalinin ana bileşenini oluşturmuş olup; Macar fiğin "Tarm beyazı", yem bezelyesinin "Szarvası andrea", yulafin "Kahraman", tritikalenin "Karma 2000" ve buğdayın "Sönmez 2000” çeşidi bitkisel materyal olarak kullanılmıştır.

Tarla denemesi, tesadüf blokları deneme desenine göre 3 tekerrürlü olarak kurulmuş olup; yem bitkileri karışımının $20 \mathrm{~cm}$ sıra aralığ mesafesinde 6 sıra halinde ekimi planlanmıştır. Çalışmada, parsel eni $120 \mathrm{~cm}$, parsel boyu 5 m'dir. 
Ekim işlemi $15 \mathrm{~kg} \mathrm{da}{ }^{-1}$ tohumluk kullanılarak mibzerle 20.09.2019 tarihinde yapılmıştır. Deneme sürecinde tarlaya gübre verilmemiştir. Gelişme dönemi boyunca yem bitkileri karışımının rutin bakım işlemleri gerçekleştirilmiştir. Çalışmada 3 farklı biçim devresi (yem bezelyesinin; çiçeklenme öncesi, \% 50 çiçeklenme dönemi ve tam çiçeklenme dönemi) araştırma konusu olarak ele alınmış olup, biçim işlemi buna göre yapılmıştır. Biçimlerde, parsel başlarından 50'şer cm ve kenarlardan ise 1'er sira kenar tesiri olarak ayrıldıktan sonra kalan alan orak yardımı ile biçilmiştir.

Her biçim döneminden sonra yem bitkileri bir süre soldurulduktan sonra 2-3 cm boyunda parçalanmıştır. Parçalanan yem bitkileri karışımına ağırlık esasına göre 0 (kontrol), \% 5, \% 10 ve \% 15 oranlarında arpa kırması ilave edilmiștir. Daha sonra bu örnekler vakum torbalarında $(25 \times 35 \mathrm{~cm})$ mutfak tipi vakum makinesinde (Lavion DZ100SS) 3 tekrarlı olarak vakumlanmış; $25 \pm 2{ }^{\circ} \mathrm{C}$ 'de 60 gün süre ile fermantasyona bırakılmıştır.

Fermantasyon süresi sonunda elde edilen silajlar açılarak; pH analizi amacıyla $25 \mathrm{~g}$ silaj örneği alınarak üzerine $250 \mathrm{ml}$ saf su eklenmiş, 30 dakika çalkalanıp elde edilen süzüğün $\mathrm{pH}$ değeri, dijital $\mathrm{pH}$ metre (HI 2211 PH /ORP METER) ile ölçülmüştür Her bir işleme ait silaj yaş materyalinden 250 gram örnek alınıp, $78{ }^{\circ} \mathrm{C}$ 'ye ayarlı etüvde 48 saat süreyle sabit ağırlı̆ga gelinceye kadar kurutulmuştur (Undersander ve ark., 1993). Kurutulan örnek yaş ağırlığa oranlanmak suretiyle silaj KM oranı belirlenmiştir. Daha sonra örnekler $2 \mathrm{~mm}$ çapında eleğe sahip bitki değirmeninde öğütülmüştür. Ham protein (HP) analizi amaciyla Dumas azot (N) tayin cihazında (Velp Scientifica NDA 701) kuru yakma yöntemiyle $\mathrm{N}$ analizi yapılmıştır (Anonymous, 2002). Elde edilen $\mathrm{N}$ değerleri 6.25 katsayısı ile çarparak HP oranları saptanmıştır. Örneklerin asit deterjan lignin (ADL), asit deterjanda çözünmeyen lif (ADF, acid detergent fiber) ve nötral deterjanda çözünmeyen lif (NDF, neutral detergent fiber) oranları ise sirasiyla Van Soest (1963) ve Van Soest ve Wine (1967)'a göre Fiber Analyzer cihazı $\left(\mathrm{ANKOM}^{200}\right.$ Fiber Analyzer, Ankom Technology, Macedon, NY, USA) kullanılarak belirlenmiştir. Silajların ham kül (HK), kalsiyum (Ca), magnezyum $(\mathrm{Mg})$ ve fosfor $(\mathrm{P})$ içerikleri FT-NIR (Fourier Transform Near Infrared, Bruker MPA, Bruker, Bremen, Germany) spektrofotometre cihazı kullanılarak ölçülmüştür.

Silaj kalitesini pratik olarak belirlemek için en fazla kullanılan yöntemlerden birisi de silajların $\mathrm{KM}$ içeriği ve $\mathrm{pH}$ değeri arasındaki ilişkiden yararlanılarak belirlenen Fleig puanı (FP) olup; FP, Eşitlik 1 yardımıyla hesaplanmıştır (Anonymous, 1987).

$$
\mathrm{FP}=[220+(2 \times \mathrm{KM} \text { oran } 1-15)]-40 \times \mathrm{pH}
$$

Elde edilen FP değerleri, Anonymous (1987) tarafından bildirilen kalite sınıfına (100-81: Çok iyi, 80-61: İyi, 60-41: Memnuniyet verici-Orta, 40-21: Düşük-değeri az, 20-0: Kötü) göre değerlendirilmiştir.

Yemlerin nispi yem değeri (NYD), Van Dyke ve Anderson (2000) tarafından geliştirilen aşağıdaki eşitlikler yardımıyla belirlenmiştir. Bunun için öncelikle; Eşitlik 2 yardımıyla sindirilebilir kuru madde (SKM, \%), Eşitlik 3 ile kuru madde tüketimi (KMT, \%) hesaplanmış, Eşitlik 4 yardımıyla da NYD saptanmıştır.

$$
\begin{aligned}
& \operatorname{SKM}(\%)=88.9-(0.779 \times \% \text { ADF }) \\
& \operatorname{KMT}(\%)=120 / \% \text { NDF } \\
& \text { NYD }(\%)=\% \text { SKM x } \% \text { KMT x } 0.775
\end{aligned}
$$

Araştırmadan elde edilen veriler; SPSS 24.0 istatistik paket programı kullanılarak tesadüf bloklarında bölünmüş parseller deneme desenine göre varyans analizine tabi tutulmuş, ortalamalar arasındaki farklılıklar Duncan çoklu karşılaştırma testi ile belirlenmiştir.

\section{Bulgular ve Tartışma}

\subsection{Hücre duvarı bileşenleri ve ham protein oranı}

Hücre duvarı bileşenlerinden olan ADF ve NDF; tükürük salgısını aktifleştirmesi ve rumendeki pH'nın uygun sınırlarda kalmasını sağlamalarına rağmen, yemlerde fazla oranda bulunması istenmeyen bir durumdur (Tekçe ve Gül, 2014). NDF kaba yemin içindeki sindirilebilen ve sindirilemeyen tüm lif oranını yansitır. ADF ve ADL, lifin selüloz ve lignin gibi zor sindirilen veya sindirilemeyen kısımları olup, yemlerde düşük bir değerde olması istenir (Van Soest, 1994). Süt sığırlarının beslenmesinde özellikle yüksek verimli sığırlarda yemlerin içeriğinde ADF oranının $\%$ 30'dan, NDF oranının da \% 40'tan düşük olması gerekmektedir (Yavuz ve ark., 2009).

Çalışmada beşli yem karışımında farklı biçim dönemlerinde elde edilen ve farklı arpa kırması uygulaması ile hazırlanan silajların hücre duvarı bileşenleri ve HP içerikleri Tablo 1'de verilmiştir. Çalışmada farklı oranlarda arpa kırması eklenen silaj örneklerinin ADF oranları arasındaki farklılık istatistiki olarak önemli $(\mathrm{p}<0.05)$ bulunmuştur. Arpa kırması uygulanan silajların ADF oranları \% 23.44-32.85 arasında değişmiş olup, en düşük değerler arpa kırması uygulanan silajlarda bulunmuştur. Silajlardaki arpa kırması oranı arttıkça ADF oranlarının azaldığı tespit edilmiştir. Biçim devrelerinin karışım silajının ADF oranına 
Tablo 1. Farklı biçim devresinde yem karışım silajına uygulanan farklı dozlarda arpa kırmasının hücre duvarı bileşenleri ve HP oranına etkisi $(\%)^{*}$

Table 1 . The effect of crushed barley doses applied to the feed mix silage at different cutting stages on cell wall components and crude protein ratio $(\%)^{*}$

\begin{tabular}{|c|c|c|c|c|c|}
\hline \multirow[b]{2}{*}{ Parametreler } & \multirow[b]{2}{*}{$\begin{array}{l}\text { Arpa kırmas1 } \\
\text { oranlar1 }\end{array}$} & \multicolumn{3}{|c|}{ Biçim devresi } & \multirow[b]{2}{*}{ Ortalama } \\
\hline & & $\begin{array}{l}\text { Çiçeklenme } \\
\text { öncesi }\end{array}$ & $\begin{array}{c}\% 50 \\
\text { çiçeklenme }\end{array}$ & $\begin{array}{c}\text { Tam } \\
\text { çiçeklenme }\end{array}$ & \\
\hline \multirow{5}{*}{$\mathrm{ADF}$} & 0 & 35.93 & 32.99 & 29.62 & $32.85 \mathrm{~A}$ \\
\hline & $\% 5$ & 25.18 & 30.01 & 25.07 & $26.75 \mathrm{~B}$ \\
\hline & $\% 10$ & 23.60 & 25.53 & 24.48 & $24.54 \mathrm{~B}$ \\
\hline & $\% 15$ & 17.47 & 27.05 & 25.81 & $23.44 \mathrm{~B}$ \\
\hline & Ortalama & 25.54 & 28.89 & 26.24 & \\
\hline \multirow{5}{*}{ NDF } & 0 & 51.49 & 58.71 & 50.86 & $53.68 \mathrm{~A}$ \\
\hline & $\% 5$ & 42.95 & 53.78 & 46.31 & $47.67 \mathrm{AB}$ \\
\hline & $\% 10$ & 42.76 & 48.28 & 44.90 & $45.31 \mathrm{AB}$ \\
\hline & $\% 15$ & 33.08 & 49.62 & 49.34 & $44.01 \mathrm{~B}$ \\
\hline & Ortalama & $42.57^{b}$ & $52.59^{\mathrm{a}}$ & $47.85^{a b}$ & \\
\hline \multirow{5}{*}{ ADL } & 0 & 5.27 & 8.12 & 5.49 & $6.29 \mathrm{~B}$ \\
\hline & $\% 5$ & 9.96 & 8.86 & 5.69 & $8.17 \mathrm{AB}$ \\
\hline & $\% 10$ & 11.56 & 10.55 & 10.04 & $10.72 \mathrm{~A}$ \\
\hline & $\% 15$ & 9.19 & 12.75 & 9.73 & $10.56 \mathrm{~A}$ \\
\hline & Ortalama & $8.99 \mathrm{ab}$ & $10.07^{\mathrm{a}}$ & $7.74^{b}$ & \\
\hline \multirow{5}{*}{ HP } & 0 & 13.50 & 16.68 & 15.40 & $15.19 \mathrm{~A}$ \\
\hline & $\% 5$ & 14.42 & 10.57 & 14.76 & $13.25 \mathrm{AB}$ \\
\hline & $\% 10$ & 11.86 & 13.22 & 17.17 & $14.08 \mathrm{AB}$ \\
\hline & $\% 15$ & 11.51 & 10.48 & 10.92 & $10.97 \mathrm{~B}$ \\
\hline & Ortalama & 13.50 & 12.74 & 14.56 & \\
\hline
\end{tabular}

*: Aynı satır ve aynı sütunda farklı harflerle belirtilen ortalamalar arasında önemli fark vardır $(\mathrm{p}<0.05)$

etkisi önemsiz bulunmuş olup, biçim devrelerine göre ADF oranı \% 25.54-28.89 arasında değişkenlik göstermiştir. Farklı oranlarda arpa kırması uygulamasının NDF ve ADL oranları arasındaki farklılık önemli olup ( $<<0.05)$; sırasıyla, \% 44.01-53.68 ve \% 6.29-10.72 arasında değişim göstermiştir. Biçim devreleri incelendiğinde; NDF oranlar1 \% 42.57-52.59 ve ADL oranlar1 \% 7.7410.07 arasında değişmiş olup, NDF ve ADL oranları yönünden biçim devresi arasındaki farklılık önemli görülmüştür $(\mathrm{p}<0.05)$. Biçim devresi geciktikçe NDF oranları artarken ADL oranları ise azalmıştır (Tablo 1). Yapılan çalışmalarda biçim devresi geciktikçe, ADF ve NDF oranlarının arttığı belirlenmiștir (Yıldırım ve Parlak, 2016; Yavuz, 2017).

Araștırmada, uygulanan arpa kırması oranlarının HP oranlarına etkisi istatistiksel açıdan $\mathrm{p}<0.05$ düzeyinde önemli çıkmıştır. Çalışmada biçim devresinin HP oranına etkisi olmadı̆̆ görülmüştür. Ham protein oranı biçim devrelerine göre \% 12.74 ile \% 14.56 arasında değişkenlik göstermiştir (Tablo 1). Yapılan bazı çalışmalarda, karışım yem bitkilerinde biçim devresi geciktikçe HP oranının azaldığ 2012; Yavuz, 2017). Bu farklılığın, silaj yapımında kullanılan arpa kırması oranının etkisinin olmasından kaynaklandığı düşünülmektedir. Arpa kırması uygulaması ile HP oranları \% 10.97-15.19 arasında değişirken; en düşük HP oranı \% 15 arpa kırması grubunda, en yüksek ise kontrol grubunda saptanmıştır (Tablo 1). Karakozak ve Ayaşan (2010), HP oranın1, inokulant katk1l1 \% 30 yulaf + $\% 70$ fiğ silajlarında \% 13.10 olarak bulmuşlardır. Yuan ve ark. (2012), saman ve ot karışımı silajlarına nemli kabuksuz arpa damıtıcıların ilave edilmesi ile HP içeriğinin arttığını, ADF ve NDF içeriğinin ise azaldığını bildirmişlerdir. Yücel ve ark. (2013), baklagil ve buğdaygil yem karışımlarından hazırlanan silajlarda inokulant uygulanması HP oranını arttırdığını, NDF ve ADF oranlarını düşürdüğünü bildirmişlerdir. Can (2010), tritikaleMacar fiği yem karışımı silajlarında enzim ve laktik asit bakterileri inokulant ilavesi ile ADL kapsamının düştüğünü ve in vitro organik madde sindiriminin arttığını tespit etmiştir. Bu çalışmada da katkı maddesinin artması ile ADF ve NDF oranları azalırken, diğer çalışmaların aksine katkı maddesinin artması ile HP oranlarında azalma ve ADL oranında ise artışa neden olmuştur. $\mathrm{Bu}$ durumun nedeni, diğer çalışmalarda silaj yapımında kullanılan katkı maddelerinin farklı olmasından kaynaklanabilir.

\subsection{Ham kül ve mineral maddeler}

Ham kül yemdeki inorganik maddeleri ifade ettiği gibi yeme sonradan karışmış toz, toprak vb. gibi maddeleri de kapsamaktadır (Kutlu, 2008). Kaba yemlerde süt ve besi hayvanları için \% 0.18- 
0.39 arasında $\mathrm{P}, \%$ 0.18-0.44 arasında Ca ve \% 0.040.10 arasında $\mathrm{Mg}$ olması gerekir (Tekeli ve Ateş, 2005).

Çalışmada farklı biçim devresinde beşli yem karışımından elde edilen silajların $\mathrm{HK}$ ve mineral madde (Ca, $\mathrm{Mg}$ ve $\mathrm{P}$ ) oranları Tablo 2'de verilmiştir. Çalışmada HK yönünden, biçim devresi ve arpa kırması uygulamaları arasındaki farklılık önemli ( $p>0.05)$ olmamıştır. Biçim devresine göre HK oranları \% 7.65-8.27 arasında değişmiştir (Tablo 2). Karışım yem bitkilerinde biçim devresi ilerledikçe $\mathrm{HK}$ oranlarının azaldığı bildirilmiştir (Gülümser ve Acar, 2017). Arpa kırması uygulama oranları incelendiğinde; en düşük değer kontrolde (\% 7.35), en yüksek değer ise \% 10 arpa kırmas1 uygulanan silajda (\% 8.35) saptanmıştır (Tablo 2).

Farklı biçim devresi ve farklı oranlarda arpa kırması uygulanmasındaki yem karışımı silajlarından elde edilen $\mathrm{Ca}$ oranları arasındaki farkların istatistiki açıdan önemli $(\mathrm{p}<0.05)$ olduğu görülmüştür. Biçim devrelerine göre elde edilen silajların $\mathrm{Ca}$ içerikleri \% $1.30-1.68$ arasında değişmiştir. Biçim devresinin ilerlemesine ve artan oranda arpa kırması uygulamasına bağlı olarak $\mathrm{Ca}$ oranları azalmıştır. Arpa kırması oranı uygulamasında, söz konusu farklılık kontrol grubu ile diğer uygulama konuları arasında ortaya çıkmış olup, en yüksek $\mathrm{Ca}$ oranı \% 1.67 ile kontrol grubunda elde edilmiştir. Çalışmada, $\mathrm{Mg}$ ve $\mathrm{P}$ oranları yönünden biçim devreleri arasındaki farklılıklar istatistiki açıdan önemli olmuştur $(p<0.05) . M g$ ve $P$ oranları sirasiyla, \% $\quad 0.62-0.73$ ve \% $0.37-0.40$ arasında değişmiş olup; biçim devrelerinin ilerlemesine paralel olarak genelde silajların Mg ve P içerikleri azalmıştır (Tablo 2). Çalışmamız sonuçlarına benzer olarak, yem bitkilerinin olgunlaşması ile mineral madde içeriklerinin azaldığı diğer bazı çalışmalarda da bildirilmiştir (Taş, 2011; Gülümser ve Acar, 2017). Elde edilen silajların $\mathrm{Mg}$ ve $\mathrm{P}$ içeriğine arpa kırmasının etkisi istatistiki olarak önemsiz çıkmış olup; arpa kırması oranlarına göre silajların $\mathrm{Mg}$ içeriği \% 0.65-0.74, P içeriği \% 0.37-0.39 arasında değişim göstermiştir. Çalışmada ayrıca, Mg oranı yönünden, biçim devresi $\mathrm{x}$ arpa kırması uygulaması interaksiyonu istatistiki açıdan önemli $(p<0.05)$ bulunmuştur. Silajlarda en yüksek $\mathrm{Mg}$ oranı \% 10 arpa kırması uygulaması ve tam çiçeklenme devresinde ( $\% 0.86)$, en düşük ise $\% 5$ arpa kırması uygulaması ve \% 50 çiçeklenme devresinde (\% $\left.\begin{array}{ll}\% & 0.51\end{array}\right)$ elde edilmiştir (Tablo 2). Soya ve börülcenin kullanıldığı bir çalışmada, uygulanan arpa kırması oranı arttıkça $\mathrm{Ca}, \mathrm{Mg}$ ve $\mathrm{P}$ içeriklerinin azaldığı rapor edilmiştir (Gülümser ve ark., 2019).

Tablo 2. Farklı biçim devresinde yem karışım silajına uygulanan farklı dozlarda arpa kırmasının HK ve mineral madde oranlarına etkisi $(\%)^{*}$

Table 2. The effect of crushed barley doses applied to the feed mix silage at different cutting stages on crude ash and mineral matter ratios $(\%)^{*}$

\begin{tabular}{|c|c|c|c|c|c|}
\hline \multirow[b]{2}{*}{ Parametreler } & \multirow{2}{*}{$\begin{array}{c}\text { Arpa kırması } \\
\text { oranları }\end{array}$} & \multicolumn{3}{|c|}{ Biçim devresi } & \multirow[b]{2}{*}{ Ortalama } \\
\hline & & $\begin{array}{c}\text { Çiçeklenme } \\
\text { öncesi }\end{array}$ & $\begin{array}{c}\% 50 \\
\text { çiçeklenme }\end{array}$ & $\begin{array}{c}\text { Tam } \\
\text { çiçeklenme }\end{array}$ & \\
\hline \multirow{5}{*}{ HK } & 0 & 5.20 & 9.01 & 7.83 & 7.35 \\
\hline & $\% 5$ & 8.66 & 8.04 & 7.87 & 8.19 \\
\hline & $\% 10$ & 8.49 & 7.94 & 8.61 & 8.35 \\
\hline & $\% 15$ & 8.23 & 8.09 & 7.64 & 7.99 \\
\hline & Ortalama & 7.65 & 8.27 & 7.99 & \\
\hline \multirow{5}{*}{$\mathrm{Ca}$} & 0 & 1.97 & 1.52 & 1.52 & $1.67 \mathrm{~A}$ \\
\hline & $\% 5$ & 1.69 & 1.27 & 1.84 & $1.60 \mathrm{AB}$ \\
\hline & $\% 10$ & 1.65 & 1.24 & 1.54 & $1.47 \mathrm{AB}$ \\
\hline & $\% 15$ & 1.44 & 1.18 & 1.31 & $1.30 \mathrm{~B}$ \\
\hline & Ortalama & $1.68^{\mathrm{a}}$ & $1.30^{\mathrm{b}}$ & $1.55^{\mathrm{a}}$ & \\
\hline \multirow{5}{*}{$\mathrm{Mg}$} & 0 & $0.71 \mathrm{a}-\mathrm{d}$ & 0.61 dce & $0.65 \mathrm{~b}-\mathrm{e}$ & 0.66 \\
\hline & $\% 5$ & $0.71 \mathrm{a}-\mathrm{d}$ & $0.51 \mathrm{e}$ & $0.72 \mathrm{a}-\mathrm{d}$ & 0.65 \\
\hline & $\% 10$ & $0.79 \mathrm{abc}$ & $0.58 \mathrm{de}$ & $0.86 \mathrm{a}$ & 0.74 \\
\hline & $\% 15$ & $0.72 \mathrm{a}-\mathrm{d}$ & $0.80 \mathrm{ab}$ & $0.60 \mathrm{de}$ & 0.71 \\
\hline & Ortalama & $0.73^{\mathrm{a}}$ & $0.62^{b}$ & $0.70^{\mathrm{ab}}$ & \\
\hline \multirow{5}{*}{$\mathrm{P}$} & 0 & 0.40 & 0.40 & 0.35 & 0.38 \\
\hline & $\% 5$ & 0.41 & 0.36 & 0.39 & 0.39 \\
\hline & $\% 10$ & 0.40 & 0.36 & 0.39 & 0.38 \\
\hline & $\% 15$ & 0.39 & 0.38 & 0.36 & 0.37 \\
\hline & Ortalama & $0.40^{\mathrm{a}}$ & $0.38^{\mathrm{ab}}$ & $0.37^{\mathrm{b}}$ & \\
\hline
\end{tabular}

*: Aynı satır ve aynı sütunda farklı harflerle belirtilen ortalamalar arasında önemli fark vardır $(\mathrm{p}<0.05)$ 


\subsection{Kuru madde, pH ve Fleig puanı}

Çalışmada farklı biçim devresi ve farklı arpa kırması uygulaması ile elde edilen silajların KM, pH ve FP değerleri Tablo 3'te verilmiştir. Farklı biçim devresindeki KM, $\mathrm{pH}$ ve FP değerleri arasındaki farkın istatistiksel olarak önemli $(p<0.05)$ olduğu görülmüştür. Buna karşılık arpa kırması oranlarının adı geçen bu parametrelere etkisi önemsiz çıkmıştır. Silaj karışımlarının KM oranları biçim devresine göre \% 19.49-40.62 arasında değişmiştir. Biçim devresi ilerledikçe KM oranları artmıştır (Tablo 3). Çalışmamız bulgularının aksine, Dumlu ve Tan (2009) silajlarda katk1 maddelerinin KM oranını arttırdığını bildirmişlerdir. Karakozak ve Ayaşan (2010), \% 70 mısır $+\% 0$ soya karışım silajlarında inokulant kullanılması ile KM oranını \% 16.88 olarak tespit etmişlerdir.

Elde edilen silajların $\mathrm{pH}$ değerleri incelendiğinde; arpa kırması uygulamalarının $\mathrm{pH}$ değerine etkisi önemsiz iken, biçim devresi uygulamalarının etkisi anlamlı bulunmuştur. Çalışmada, biçim devresine göre $\mathrm{pH}$ değeri 4.434.96 arasında değişim göstermiştir (Tablo 3). Silaj pH'sının istenilen düzeyin biraz üzerinde olması, Dumlu ve Tan (2009) tarafindan da belirtildiği üzere, karışımdaki baklagil yem bitkilerinin buğdaygil yem bitkileri oranından daha fazla olmasından kaynaklandığı düşünülmektedir. Kuru madde ve $\mathrm{pH}$ yönünden elde edilen bu sonuçlar doğal olarak FP sonuçlarına da yansımış ve Fleig puanları sonucu yapılan sinıflandırmada, elde edilen silajların "iyi” ve "pekiyi”" kalitede olduğu görülmüştür. Biçim devresine göre Fleig puanları
48.99-103.11 arasında, arpa kırması uygulamasında ise 64.97-87.50 arasında değişmiştir (Tablo 3). Kontrole göre arpa kırması oranının artması ile silajda karbonhidrat kaynağını artırarak pH değerinin azalmasına ve Fleig puanının artmasına neden olmuştur.

Biçim devresi $\mathrm{x}$ arpa kırması uygulaması interaksiyonu, $\mathrm{pH}$ ve FP parametrelerinde önemli düzeyde etkili olmuştur $(p<0.05)$. Silajlarda en yüksek $\mathrm{pH}$, çiçeklenme öncesinde biçilen ve arpa kırması eklenmeyen kontrol uygulamasinda (5.62), en düşük ise $\% 5$ arpa kırması ilave edilen ve $\% 50$ çiçeklenme döneminde biçilen silaj örneklerinden (4.36) elde edilmiştir (Tablo 3). Benzer olarak, Gülümser ve ark. (2019), silajlara ilave edilen melas ve arpa kırmasının silaj $\mathrm{pH}$ değerlerini azalttığını belirlemişlerdir. FP değeri en yüksek \% 5 arpa kırması uygulaması ve \% 50 çiçeklenme döneminde (113.80), en düşük kontrolde ve çiçeklenme öncesi dönemde (10.98) tespit edilmiştir. Biçim devresinin ilerlemesi ve silajlarda arpa kırmasının oranının artması, Fleig puanının yükselmesini sağlamıştır (Tablo 3). Elde edilen FP ortalamalarının aksine yapılan çalışmalarda, yem karışımları silajı Fleig puanlarının 100 ve üzeri olduğu tespit edilmiştir (Öten ve ark., 2016; Gelir, 2018; Seydoşoğlu, 2019). Baklagiller familyasından bitki türleriyle yapılan silajlarda $\mathrm{pH}$ yükselmektedir (Kökten ve ark., 2013). Karışım silajlarında baklagil oranının artışına bağlı olarak pH artmakta, dolayısıyla FP da düşmektedir (Saruhan ve ark., 2011). Çalışmada kullanılan karışımda baklagil oranının fazla olması $\mathrm{pH}$ değerlerini yükseltmiştir. Bunun etkisi ile Fleig puanlarının yüksek olmadığı düşünülmektedir.

Tablo 3. Farklı biçim devresinde yem karışım silajına uygulanan farklı dozlarda arpa kırmasının KM $(\%)$, pH ve Fleig puanına (\%) etkisi*

Table 3 . The effect of crushed barley doses applied to the feed mix silage at different cutting stages on dry matter $(\%), \mathrm{pH}$, and Fleig score $(\%)^{*}$

\begin{tabular}{|c|c|c|c|c|c|}
\hline \multirow[b]{2}{*}{ Parametreler } & \multirow[b]{2}{*}{$\begin{array}{c}\text { Arpa kırmas1 } \\
\text { oranlar1 }\end{array}$} & \multicolumn{3}{|c|}{ Biçim devresi } & \multirow[b]{2}{*}{ Ortalama } \\
\hline & & $\begin{array}{c}\text { Çiçeklenme } \\
\text { öncesi }\end{array}$ & $\begin{array}{c}\% 50 \\
\text { çiçeklenme }\end{array}$ & $\begin{array}{c}\text { Tam } \\
\text { çiçeklenme }\end{array}$ & \\
\hline \multirow{5}{*}{ KM } & 0 & 15.39 & 36.18 & 36.37 & 29.32 \\
\hline & $\% 5$ & 17.85 & 41.60 & 38.60 & 32.68 \\
\hline & $\% 10$ & 20.57 & 35.28 & 42.47 & 32.78 \\
\hline & $\% 15$ & 24.16 & 37.66 & 45.02 & 35.61 \\
\hline & Ortalama & $19.49^{b}$ & $37.68^{a}$ & $40.62^{\mathrm{a}}$ & \\
\hline \multirow{5}{*}{$\mathrm{pH}$} & 0 & $5.62 \mathrm{a}$ & $4.44 \mathrm{de}$ & $4.83 \mathrm{bcd}$ & 4.96 \\
\hline & $\% 5$ & $4.61 \mathrm{~b}-\mathrm{e}$ & $4.36 \mathrm{e}$ & $4.99 \mathrm{bc}$ & 4.65 \\
\hline & $\% 10$ & 4.55 cde & $4.44 \mathrm{de}$ & $5.06 \mathrm{~b}$ & 4.68 \\
\hline & $\% 15$ & $4.71 \mathrm{~b}-\mathrm{e}$ & $4.48 \mathrm{de}$ & $4.96 \mathrm{bc}$ & 4.71 \\
\hline & Ortalama & $4.87^{\mathrm{a}}$ & $4.43^{b}$ & $4.96^{\mathrm{a}}$ & \\
\hline \multirow{5}{*}{ FP } & 0 & $10.98 \mathrm{e}$ & $99.57 \mathrm{ab}$ & $84.35 \mathrm{bc}$ & 64.97 \\
\hline & $\% 5$ & $56.30 \mathrm{~d}$ & $113.80 \mathrm{a}$ & $82.61 \mathrm{bc}$ & 84.24 \\
\hline & $\% 10$ & $63.95 \mathrm{dc}$ & $97.96 \mathrm{ab}$ & $87.35 \mathrm{~b}$ & 83.09 \\
\hline & $\% 15$ & $64.72 \mathrm{dc}$ & $101.12 \mathrm{ab}$ & $96.65 \mathrm{ab}$ & 87.50 \\
\hline & Ortalama & $48.99^{c}$ & $103.11^{\mathrm{a}}$ & $87.74^{b}$ & \\
\hline
\end{tabular}

*: Aynı satır ve aynı sütunda farklı harflerle belirtilen ortalamalar arasında önemli fark vardır $(\mathrm{p}<0.05)$ 
3.4. Sindirilebilir kuru madde oranı, kuru madde tüketimi, nispi yem değeri

Nispi yem değeri, yemlerin pazarlanmasında üretici ve tüketiciler tarafindan kullanılan bir özellik olup, rakamsal olarak yemin kalitesini gösteren bir ölçüdür (Marković ve ark., 2010). Nispi yem değeri indeksi, tam çiçekteki yonca için 100 indeksini esas alır. Bu değerin altında veya üstünde bulunması ile yem kalitesi düşmekte veya artmaktadır. Buna göre; NYD>151: en iyi kalite, 125-151: 1. kalite, 103-124: 2. kalite, 87-102: 3. kalite, 75-86: 4. kalite ve NYD<75: 5. kalite olarak kabul edilir (Rohweder ve ark., 1978).

Çalışmada farklı zamanlarda hasat edilen beşli yem karışımından elde edilen silajların SKM oranı, KMT ve NYD verileri Tablo 4'te verilmiştir. Çalışmada farklı miktarlarda arpa kırması uygulaması ile elde edilen silajların SKM oranı arasındaki farklar istatistiki açıdan önemli bulunmuştur $(p<0.05)$. En yüksek SKM oranı arpa kırması oranı uygulamalarında (\% 68.06-70.63), en düşük ise kontrol uygulamasında (\% 63.31) tespit edilmiştir. Kontrole göre artan oranda arpa kırması uygulaması SKM oranını arttırmıştır (Tablo 4). Benzer şekilde Canbolat ve ark. (2019), yem bezelyesi silajlarına melas ilavesinin kuru madde sindirimini arttırdığını tespit etmişlerdir. SKM oranı yönünden biçim devreleri arasında istatistiki açıdan farklılık görülmemiş olup, biçim devrelerine göre SKM oranları \% 66.38-69.00 arasında değişmiştir (Tablo 4).

Farklı biçim devrelerinde hasat edilen karışımların KMT oranları arasında önemli farklılık görülmüştür $(\mathrm{p}<0.05)$. Biçim devresine göre KMT \% 2.29-2.95 arasında değişmiştir. Biçim devresinin ilerlemesi ile artan ADF ve NDF oranından dolayı KMT azalmıştır (Tablo 4). Benzer şekilde Bayar ve Çaçan (2019), biçim zamanı geciktikçe Macar fiğinde KMT oranının azaldığını bildirmişlerdir. KMT oranı yönünden arpa kırması uygulamaları arasında istatistiki açıdan farklılık görülmemiş olup, arpa kırması uygulamalarına göre KMT oranları \% 2.24-2.84 arasında değişmiştir (Tablo 4).

Farklı biçim devreleri ve farklı arpa kırması uygulamalarının silajların NYD ortalamaları arasında istatistiki açıdan önemli farklılıklar oluşturduğu tespit edilmiştir $(p<0.05)$. Biçim devrelerinde en yüksek NYD ortalaması (161.00) çiçeklenme öncesi dönemde belirlenirken, en düşük NYD (118.63) \% 50 çiçeklenme döneminde hasat edilen karışımdan yapılan silajlardan elde edilmiştir. Silajlarda arpa kırması oranındaki artışa bağlı olarak NYD ortalamalarının arttığ görülmektedir. En yüksek nispi yem değeri (157.42) \% 15 arpa kırması uygulamasında; en düşük (110.29) ise arpa kırması uygulanmayan kontrolde belirlenmiştir. Biçim devresi geciktikçe artan ADF ve NDF oranlarından dolayı NYD oranlarında azalma görülmüştür (Tablo 4). Gülümser ve Acar (2017), biçim zamanı geciktikçe Macar fiği ve tahıl karışımının nispi yem değerinin azaldığını bildirmişlerdir. Artan arpa kırması oranı ile karışım yem bitkisi NYD oranları da artış göstermiştir. Silaj yapımında karbonhidrat kaynağının yemin nispi yem değerini arttırdığı, bu konuda yapılan çalışmalarda bildirilmiştir (Canbolat ve ark., 2019; Durmaz, 2020). Yonca silajı ile yapılan bir çalışmada, melas, arpa ezmesi ve peynir altı suyu katkı maddelerinin uygulanması ile nispi yem değerinin yükseldiği belirlenmiştir (Acar ve Bostan, 2016).

Tablo 4. Farklı biçim devresinde yem karışım silajına uygulanan farklı dozlarda arpa kırmasının SKM ve KMT oranları (\%) ile nispi yem değerine etkisi"

Table 4 . The effect of crushed barley doses applied to the feed mix silage at different cutting stages on digestible dry matter $(\%)$, dry matter intake $(\%)$, and relative feed value*

\begin{tabular}{|c|c|c|c|c|c|}
\hline \multirow[b]{2}{*}{ Parametreler } & \multirow[b]{2}{*}{$\begin{array}{l}\text { Arpa kırması } \\
\text { oranları }\end{array}$} & \multicolumn{3}{|c|}{ Biçim devresi } & \multirow[b]{2}{*}{ Ortalama } \\
\hline & & Çiçeklenme öncesi & $\begin{array}{c}\% 50 \\
\text { çiçeklenme }\end{array}$ & $\begin{array}{c}\text { Tam } \\
\text { çiçeklenme }\end{array}$ & \\
\hline \multirow{5}{*}{ SKM } & 0 & 60.91 & 63.19 & 65.82 & $63.31 \mathrm{~B}$ \\
\hline & $\% 5$ & 69.28 & 65.52 & 69.37 & $68.06 \mathrm{~A}$ \\
\hline & $\% 10$ & 70.51 & 69.00 & 69.83 & $69.78 \mathrm{~A}$ \\
\hline & $\% 15$ & 75.29 & 67.82 & 68.79 & $70.63 \mathrm{~A}$ \\
\hline & Ortalama & 69.00 & 66.38 & 68.45 & \\
\hline \multirow{5}{*}{ KMT } & 0 & 2.33 & 2.04 & 2.36 & 2.24 \\
\hline & $\% 5$ & 2.79 & 2.23 & 2.59 & 2.54 \\
\hline & $\% 10$ & 3.03 & 2.48 & 2.69 & 2.74 \\
\hline & $\% 15$ & 3.66 & 2.42 & 2.44 & 2.84 \\
\hline & Ortalama & $2.95^{\mathrm{a}}$ & $2.29^{b}$ & $2.52^{\mathrm{ab}}$ & \\
\hline \multirow{5}{*}{ NYD } & 0 & 110.06 & 100.24 & 120.58 & $110.29 \mathrm{~B}$ \\
\hline & $\% 5$ & 150.23 & 113.44 & 139.36 & $134.34 \mathrm{AB}$ \\
\hline & $\% 10$ & 169.74 & 133.25 & 146.60 & $149.86 \mathrm{AB}$ \\
\hline & $\% 15$ & 213.97 & 127.59 & 130.68 & $157.42 \mathrm{~A}$ \\
\hline & Ortalama & $161.00^{\mathrm{a}}$ & $118.63^{b}$ & $134.30^{\mathrm{ab}}$ & \\
\hline
\end{tabular}

*: Aynı satır ve aynı sütunda farklı harflerle belirtilen ortalamalar arasında önemli fark vardır $(\mathrm{p}<0.05)$ 


\section{Sonuçlar}

Çalışmada biçim devresi geciktikçe yemin besin madde içerikleri ile yem değerinin azaldığ 1 , silaj yapımında arpa kırması oranının artması ile besin madde içerikleri ile yem değerinin arttığ1 belirlenmiştir. Sonuç olarak yılın her mevsiminde hayvanların yeşil yem ihtiyacını karşılamak amacı ile yem bitkilerinin yer aldığı çoklu karışımların ana ürün olarak yetiştirilip \% 50 çiçeklenme devresinde biçilerek, \% 15 arpa kırması kullanılması ile hazırlanan silajlarla, hayvanların kaliteli kaba yem ihtiyaçlarının karşılanabileceği söylenebilir.

\section{Kaynaklar}

Acar, Z., Bostan, M., 2016. Değişik doğal katk1 maddelerinin yonca silajının kalitesine etkilerinin belirlenmesi. Anadolu Tartm Bilimleri Dergisi, 31(3): 433-440.

Akdağ, A., Garipoğlu, A.V., 2018. Yem bitkilerinin muhafazasında alternatif bir yaklaşım: mikrobiyal koruyucular. Black Sea Journal of Agriculture, 1(1): 23-26.

Anonymous, 1987. Bewertung Von Grünfutter, Silage Und Heu. Dlg-Merkblatt, No. 224. Dlg-Verlag, Frankfurt/M.

Anonymous, 2002. AOAC Official Method 990.03. Official Methods of Analysis of AOAC International, 18th Ed., AOAC International, Gaithersburg, MD.

Bakır, Ö., 1987. Çayır Mera Yönetimi. Ankara Üniversitesi Ziraat Fakültesi, Yayın No: 992, Ankara.

Bayar, M., Çaçan, E., 2019. Farklı zamanlarda hasat edilen Macar fiğinde (Vicia pannonica Crantz) ot verimi ve bazı kalite özelliklerinin değişimi. 1. Uluslararası Harran Multidisipliner Çalışmalar Kongresi, 8-10 Mart, Şanlıurfa, s. 322-330.

Can, L., 2010. Tritikale-Macar fiği hasılına enzim ve laktik asit bakterileri inokulant ilavesinin silaj kalitesi üzerine etkileri. Yüksek lisans tezi, Tekirdağ Namık Kemal Üniversitesi, Fen Bilimleri Enstitüsü, Tekirdağ.

Canbolat, Ö., Akbay, K.C., Kamalak, A., 2019. Yem bezelyesi silajlarında karbonhidrat kaynağ 1 olarak melas kullanılma olanakları. Kahramanmaraş Sütçü Imam Üniversitesi Tarım ve Doğa Dergisi, 22(1): 122-130.

Çiftçi, M., Çerci, İ.H., Dalkılıç, B., Güler, T., Ertaş, O.N., 2006. Elmanın karbonhidrat kaynağı olarak yonca silajına katılma olanağının araştırılması. Yüzüncü $Y l l$ Üniversitesi Veteriner Fakültesi Dergisi, 16(2): 9398.

Demirel, R., Saruhan, V., Baran, M.S., Andiç, N., Şentürk, D., 2010. Farklı oranlarda ak üçgül (Trifolium repens) ve arpa (Hordeum vulgare L.) karışımlarının silolanma özelliklerinin belirlenmesi. Yüzüncü Yıl Üniversitesi Tarım Bilimleri Dergisi, 20(1): 26-31.

Dumlu, Z., Tan, M., 2009. Erzurum şartlarında yetișen bazı baklagil yem bitkileri ve karışımlarının silaj değerlerinin belirlenmesi. Atatürk Üniversitesi Ziraat Fakültesi Dergisi, 40(2): 15-21.

Durmaz, S., 2020. Kolzanın silolanabilirlik özellikleri ve yem değerinin belirlenmesi. Yüksek lisans tezi, Bursa Uludağ Üniversitesi, Fen bilimleri Enstitüsü, Bursa.

Gelir, G., 2018. Diyarbakır koşullarında yetiştirilen yem bezelyesi (Pisum sativum subs arvense L.), tritikale ve karışımların silaj kalite özelliklerinin belirlenmesi. Yüksek lisans tezi, Dicle Üniversitesi, Fen Bilimleri Enstitüsü, Diyarbakır.

Gülümser, E., Acar, Z., 2017. Biçim zamanı ve tohum oranlarının Macar fiği tahıl karışımlarının bazı kalite özellikleri üzerine etkisi. Selçuk Tarım ve Gıda Bilimleri Dergisi, 31(2): 14-21.

Gülümser, E., Mut, H., Başaran, U., Doğrusöz, M.Ç., 2019. Melas veya arpa kırması ilavesinin börülce ve soya silajlarının kalitesi üzerine etkisi. Bilecik Şeyh Edebali Üniversitesi Fen Bilimleri Dergisi, Prof. Dr. Fuat SEZGIN Bilim Yılı Özel Sayısl, 6: 161-167.

Gürsoy, E., Macit, M., 2020. Hasat zamanının kaba yemin kimyasal kompozisyonu ve kalitesi üzerine etkisi. Euroasia Journal of Mathematics, Engineering, Natural \& Medical Sciences International Indexed \& Refereed, 8(9): 168-177.

Haigh, P.M., 1988. The effect of wilting and silage additives on the fermentation of autmn made grass silage ensiled in bunkers on commercial farms in south wales. Grass and Forage Science, 43(3): 337345.

Karakozak, E., Ayaşan, T., 2010. Değişik yem bitkileri ve karışımlarından hazırlanan silajlarda inokulant kullanımının fleig puanı ve ham besin maddeleri üzerine etkileri. Kafkas Üniversitesi Veteriner Fakültesi, 16(6): 987-994.

Kökten, K., Boydak, E., Kaplan, M., Seydoşoğlu, S., Kavurmac1, Z., 2013. Bazı soya fasulyesi (Glycine $\max$ L.) çeşitlerinden yapılan silajların besin değerlerinin belirlenmesi. Türk Doğa ve Fen Dergisi, 2(2): 7-10.

Kutlu, H.R., 2008. Yem Değerlendirme ve Analiz Yöntemleri. Çukurova Üniversitesi, Ziraat Fakültesi, Ders Notları, Adana.

Marković, J., Štrbanović, R., Terzić, D., Pojić, M., Vasić, T., Babić, S., 2010. Relative feed value of alfalfa (Medicago sativa L.) and red clover (Trifolium pratense L.) at different stage of growth. Biotechnology in Animal Husbandry, 26(Special Issue): 469-474.

McDonald, P., Henderson, A.R., Heron, S.J.E., 1991. The Biochemistry Of Silage. 2nd Edition. Marlow, Bucks, UK: Chalcombe Publications.

Rohweder, D.A., Barnes, R.F., Jorgensen, N., 1978. Proposed hay grading standards based on laboratory analyses for evaluating quality. Journal of Animal Science, 47(3): 747-759.

Önal, A.O., Acar, Z., 2018. Kaba Yemlerde Kalite. Ziraat Mühendisleri Odası Yayınları, Ankara.

Öten, M., Kiremitçi, S., Çınar, O., 2016. Farklı oranlarda hazırlanan bazı yem bitkileriyle yapılan silajlarda 
kalite parametrelerinin belirlenmesi amaciyla yapılan bir çalışma. Anadolu, 26(2): 33- 43.

Özyazıcı, M.A., Açıkbaş, S., 2019. Phosphorus, potassium, calcium and magnesium content of roughage and importance on animal nutrition. ISPEC International Conference on Agriculture, Animal Science and Rural Development-III, December 2022, Van, Turkey, pp. 553-568.

Sarıçiçek, B.Z., Kılıç, Ü., 2009. The effects of different additives on silage gas production, fermentation kinetics and silage quality. Ozean Journal of Applied Sciences, 2 (1): 11-18.

Saruhan, V., Demirel, R., Baran, M.S., Şentürk Demirel, D., 2011. Sarı çiçekli gazal boynuzu (Lotus corniculatus) ve arpanın (Hordeum vulgare) farklı düzeylerdeki karışımlarının silolanma özelliklerinin belirlenmesi. Anadolu Tartm Bilimleri Dergisi, 26(1): 40-45.

Seydoşoğlu, S., 2019. Farklı oranlarda karıștırılan yem bezelyesi (Pisum sativum L.) ve arpa (Hordeum vulgare L.) hâsıllarının silaj ve yem kalitesine etkisi. Ege Üniversitesi Ziraat Fakültesi Dergisi, 56(3): 297-302.

Sturludóttir, E., 2011. Forage quality and yield in grasslegume mixtures in northern Europe and Canada. M.Sc. thesis, University of Iceland, Faculty of Physical Sciences, Reykiavik.

Taş, N., 2011. Kuru şartlarda yazlık ve güzlük ekilen fiğ+buğday karışımlarında en uygun karışım şekli, karıșım oranı ve biçim zamanının ot verimi ve verim unsurları üzerine etkisi. Anadolu, 21(1): 1-15.

Tekçe, E., Gül, M., 2014. Ruminant beslemede NDF ve ADF'nin önemi. Atatürk Üniversitesi Veteriner Bilimleri Dergisi, 9(1): 63-73.

Tekeli, A.S., Ateş, E., 2005. Yield potential and mineral composition of white clover (Trifolium repens L.)tall fescue (Festuca arundinacea schreb.) mixtures. Journal of Central European Agriculture, 6(1): 2734.

Türemiş, A., Kızılşimşek, M., Kızıl, S., İnal, İ., Sağlamtimur, T., 1997. Bazı katk1 maddelerinin çukurova koşullarında yetiştirilebilen bazı yazlık yem bitkileri ve karışımlarından yapılan silajlar üzerine etkilerinin saptanması üzerinde bir araştırma. Türkiye I. Silaj Kongresi, 16-19 Eylül, Bursa, s. 166-175.

Undersander, D., Mertens, D.R., Thiex, N., 1993. Forage Analyses Procedures. South Dakota State University, National Forage Testing Association, Omaha Nebraska.
Uzun, A., Asik, F.F., 2012. The effect of mixture rates and cutting stages on some yield and quality characters of pea (Pisum sativum L.) + oat (Avena sativa L.) mixture. Turkish Journal of Field Crops, 17(1): 62-66.

Van Dyke, N.J., Anderson, P.M., 2000. Interpreting a Forage Analysis. Alabama Cooperative Extension, Circular ANR-890, Alabama.

Van Soest, P.J., 1963. The use of detergents in the analysis of fiber feeds. II. A rapid method for the determination of fiber and lignin. Journal of the Association of Official Analytical Chemists, 46(5): 829-835.

Van Soest, P.J., 1994. Nutritional Ecology of the Ruminant (2nd Ed.). Ithaca, N.Y. Cornell University Press.

Van Soest, P.J., Wine, R.H., 1967. Use of detergents in the analysis of fibrous feeds. IV. Determination of plant cell-wall constituents. Journal Association of Official Analytical Chemists, 50(1): 50-55.

Yavuz, T., 2017. Farklı biçim zamanlarının yem bezelyesi (Pisum sativum L.) ve yulaf (Avena sativa L.) karışımlarında ot verim ve kalitesi üzerine etkileri. Tarla Bitkileri Merkez Araştırma Enstitüsü Dergisi, 26(1): 67-74.

Yavuz, M., İptaş, S., Ayhan, V., Karadağ, Y., 2009. Yem bitkilerinde kalite ve yem bitkilerinden kaynaklanan beslenme bozuklukları. R. Avcioğlu, R. Hatipoğlu ve Y. Karadağ (Editörler), Yem bitkileri, Genel Bölüm, Tarım ve Köyişleri Bakanlığı, Tarımsal Üretim ve Geliştirme Genel Müdürlüğü, Cilt I, İzmir.

Yıldırım, S., Parlak, A.Ö., 2016. Tritikale ile bezelye, bakla ve fiğ karıșım oranlarının belirlenerek yem verimi ve kalitesine etkileri. Çanakkale Onsekiz Mart Üniversitesi Ziraat Fakültesi Dergisi, 4(1): 77-83.

Yitbarek, M.B., Tamir, B., 2014. Silage additives: Review. Open Journal of Applied Sciences, 4(5): 258274.

Yuan, X., Yu, C., Shimojo, M., Shao, T., 2012. Improvement of fermentation and nutritive quality of straw-grass silage by inclusion of wet hulless-barley distillers' grains in Tibet. Asian-Austtralasian Journal of Animal Science, 25(4): 479-485.

Yücel, C., Avcı, M., Kılıçalp, N., Akkaya, M.R., 2013. Lactobacillus buchneri ile silolanmış baklagil, buğdaygil ve karışımlarının silaj özellikleri. Tekirdă̆ Ziraat Fakültesi Dergisi, 10(3): 11-18. 